\author{
MILJANA S. PAVIĆEVIĆ ${ }^{1}$ \\ JELENA LJ. MINIĆ ${ }^{2}$ \\ UNIVERSITY OF PRIŠTINA IN KOSOVSKA MITROVICA \\ FACULTY OF PHILOSOPHY \\ DEPARTMENT OF PSYCHOLOGY
}

\title{
ANXIETY AND REINFORCEMENT SENSITIVITY IN ADOLESCENTS
}

\begin{abstract}
Theoretical background of this paper is Gray's reformulated reinforcement sensitivity theory and Spielberger's model of anxiety as a personality trait. It is a well-founded and a well-known conception which is also highly controversial. The paper is a part of a larger research on mental health of the Kosovo and Metohija youth. The aim of this research is to examine predictive power of trait anxiety in predicting reinforcement sensitivity (through the systems: FFF; BIS, and BAS). The sample of the research encompassed adolescents $(\mathrm{N}=138)$. Results gained point that the anxiety trait is more rendered in those adolescents with more inhibition and avoidance exhibited, as well as BIS. Also, trait anxiety is more rendered in the adolescents with a lower BAS. Statistically significant relationship between trait anxiety and the fight is not found. Persons with more exhibited anxiety show inability to react to endangering situations, they step back to avoid new situations, and perceive their environment as a source of potential danger.
\end{abstract}

KEYWORDS: anxiety; reinforcement sensitivity; adolescents.

\footnotetext{
miljanapavicevic@yahoo.com

jelena.minic@pr.ac.rs

Рад је примљен 18. августа 2018, а прихваћен за објављивање на састанку Редакције 3ठорника одржаном 18. марта 2019.
} 


\section{INTRODUCTION}

Theoretical basis of the paper is Gray's reformulated reinforcement theory (Gray \& McNaughton, 2003), with three basic systems, their behavioural functions and neurological substrates. These systems are such as follows: 1) behavioural inhibition system (BISbehavioural inhibition system) which regulates passive avoidance reactions to the reward cues (including frustration caused by the lack of reward ); 2) behavioural activation system (BAS- behavioural approach system) responsible for the control of active approach and behaviour as a response to reward cues (including "relief" for avoiding the punishment); 3) system Fight/Flight/Freeze (FFF), consisting of three basic patterns of reactions to a real or potential danger. In a reformulated model, BIS becomes a system responsible for detecting conflict between the two averse (FFF-FFF) or two appetitive (BAS-BAS) stimuli. It is a system responsible for reacting to all conditioned stimuli in case when they are in any kind of conflict relationship. It is activated in situations when the person is forced to react, but also in case of experiencing a high degree of distress due to the detection of potential danger. BIS system is related to anxiety (Corr, 2004). BAS remains a system responsive to the reward cue in a reformulated model (incorporating both conditioned and unconditioned reactions to reward cues and a relief due to the avoiding of punishment), it is responsible for an active approach which corresponds to impulsive trait, and according to Corr (2004) this system is related to positive affect. As far as the system of Fight/Flight/Freeze is concerned, it is responsible for all types of behaviour related to states of fear (Žuljević \& Gavrilov-Jerković, 2011). These reactions are provoked by stimuli which present unconditioned punishment or lack of reward, but also conditioned reward cues or lack of reward. This system mediates in reactions to all aversive stimuli, and possible reactions to threatening stimuli may be fight, flight, or "freezing". Thus, this system also takes over a part of responsibility for reactions which had been attributed to BIS in the original model (Mitrović, Smederevac \& Čolović, 2008), it is relevant to the status of negative affect (related to pain) and Eysenck's dimension of psychoticism (Corr, 2004).

By surveying the literature, it is possible to find a large number of definitions of anxiety. One of the adopted definitions is by Spielberger (2000), who differentiates anxiety as a state from anxiety as a 
personality trait. Anxiety as a state is defined by Spielberger (2000) as an emotional reaction consisting of unpleasant, consciously perceived feelings of tension, trepidation, nervousness, and worry, followed by activation or excitement of the autonomous nervous system. Anxiety as a personality trait for Spielberger (2000) means a measurement of individual differences and tendencies to anxiety in regard to the possibility that state of anxiety will be manifested in the circumstances which include different degrees of stress. Thus defined anxiety refers to the proportionally stable individual tendency to anxiety (Spielberger, 2000). According to Spielberger (2000) anxiety is unidimensional construct, where anxiety trait represents a stable disposition, while consistency of anxious reaction refers to a wide spectre of situations, as well as time stability of this tendency. Anxiety encompasses modulation of a previous fear or frustration. Also, in natural situations, there is a strong correlation between insecurity and a threat and a need to get closer to the source of potential threat. Anxiety trait refers to the general tendency of an individual to react anxiously to potentially provoking anxious stimuli (Taylor, 1995). By means of trait anxiety, it is possible to predict future symptoms of anxiety on the basis of past, similar experiences (Vulić-Prtorić, 2006).

A survey of research on the topic of reformulated Gray's reinforcement sensitivity theory leaves an impression that most of the studies on the issue are concerned with stress prevalence. In favour of it, there are studies of relations between dimensions of reformulated Gray's personality models, attributive styles and strategies of stress prevalence (Brdarić and Gavrilov-Jerković, 2011), also strategies of stress prevailing in the context of the afore mentioned theory (Žuljević \& Gavrilov-Jerković, 2011) and alike.

Gray's reinforcement sensitivity theory (1985) is a well-founded and well-known conception, but it is also a theory which aroused numerous controversies. The reinforcement sensitivity theory of personality is considered as one of the most controversial theories in psychology of personality (Mitrović, Smederevac \& Čolović, 2008). Taking into account the afore mentioned, as well as the fact that there is almost no research which studies relationship between predictive power of trait anxiety and reinforcement sensitivity, we have tried to improve the scene of research in our country in regard to this theory and its use. We also thought that it would be interesting to examine adolescents i.e. subjects in the period of developmental crisis, which is provocative due to a number of symptoms. 
The paper deals with relationship between anxiety and the constructs of reformulated reinforcement sensitivity theory. It is about a well-founded and well-known conception, a reformulated reinforcement sensitivity theory. The paper is a part of a wider research of the mental health of Kosovo and Metohija youth. It aims to examine the relationship between trait anxiety and reinforcement sensitivity (through the systems: FFF; BIS and BAS), i.e. examination of predictive power of trait anxiety in predicting the three patterns of reactions in the adolescents. The sample encompassed adolescents $(\mathrm{N}=138,67$ males and 71 females; AS=22.67; $\mathrm{SD}=2.23$; students of the first grade of study and pupils of final grades of secondary schools, with a permanent residence in Kosovo and Metohija and Serbia proper). The basic assumption referred to the relationship between anxiety and reinforcement sensitivity and the presence of predictive power of trait anxiety in predicting patterns of reactions of adolescents.

Trait anxiety was operationalized via Scale for assessment of trait anxiety (AT29 scale) (Tovilović \& Novović, 2009). Anxiety presents narrower trait of Neuroticism as a basic dimension of personality and is characterized by frequent tension experience (Smederevac, Mitrović \& Čolović, 2010). Trait anxiety (Spielberg, Gorsuch \& Lushene, 1970) refers to the presence of stable individual differences with tendency to respond with an anxiety in the anticipation of threatening situations. The five-degree scale of Likert type was used, comprising 29 items, and high scores on the scale suggest vulnerability to anxiety disorders. The authors state reliability of the scale gained by Cronbach's $\alpha=.96$, while our sample reliability is $\alpha=.97$.

Reinforcement sensitivity expressed through the behavioural inhibition system (BIS), behavioural activation (BAS), and system Fight/Flight/Freezing were conducted by the use of Questionnaire for assessment of reinforcement sensitivity (UOP questionnaire) (Smederevac, Čolović and Mitrović, 2009). The five-degree scale of Likert type consisted of 39 items distributed into five subscales. The authors state satisfying reliability of the instruments (Cronbach's alpha over .80 for all subscales), and on our sample reliability of individual systems gained by Cronbach's $\alpha$ is: $\mathrm{BIS}=.86$; $\mathrm{BAS}=.80$; Flight $=.84$; Freezing $=.89$; Fight $=.83$. 


\section{RESULTS}

Results of correlation and regression analysis will be presented in the tables as follows:

\begin{tabular}{|c|c|c|c|c|c|}
\hline & BIS & BAS & FIGHT & AVOIDANCE & INHIBITION \\
\hline ANXIETY & $.628^{* *}$ & $-.263^{* *}$ & -.086 & $.453^{* *}$ & $.550^{* *}$ \\
\hline
\end{tabular}

TABLE 1: RELATIONSHIP BETWEEN TRAIT ANXIETY AND REINFORCEMENT SENSITIVITY

*Correlation significant on level $\mathrm{p}<0.05$

**Correlation significant on level $\mathrm{p}<0.01$

Our results show that trait anxiety realizes positive correlation with inhibition, avoidance and BIS, and a negative one with BAS. Trait anxiety is more rendered in those adolescents with exhibited inhibition and avoidance, as well as the system of behavioural inhibition, while trait anxiety is even more rendered in those adolescents whose system of behavioural activation is lower. Adolescents with a more exhibited anxiety show inability to react to endangering situations, step back to avoid new situations, and perceive their environment as a source of potential danger. Statistically significant relationship between trait anxiety and the fight is not found.

Model of multiple regression for assessing predictive power of trait anxiety in predicting reinforcement sensitivity was used. Results (see Table 2) show that trait anxiety is a significant predictor in predicting system of behavioural inhibition $(\mathrm{F}=89.086, \mathrm{p}=0.000)$ and explains $39.4 \%$ variance BIS

\begin{tabular}{|c|c|c|c|c|c|c|}
\hline & $\Delta \mathrm{R}$ & $\mathrm{F}$ & SIG. & $\mathrm{B}$ & $\mathrm{t}$ & SIG. \\
\hline ANXIETY & .394 & 89.086 & .000 & .628 & 9.439 & .000 \\
\hline
\end{tabular}

TABLE 2: ANXIETY AS PREDICTOR OF BIS

*Significant on level $\mathrm{p}<0.05$

Trait anxiety is significant in predicting avoidance $(\mathrm{F}=35.453$, $\mathrm{p}=0.000$ ) and explains $20.5 \%$ variance of avoidance. 


\begin{tabular}{|c|c|c|c|c|c|c|}
\hline & $\Delta \mathrm{R}$ & $\mathrm{F}$ & SIG. & $\mathrm{B}$ & $\mathrm{t}$ & SIG. \\
\hline ANXIETY & .205 & 35.435 & .000 & .453 & 5.953 & .000 \\
\hline \hline
\end{tabular}

TABLE 3: ANXIETY AS PREDICTOR OF AVOIDANCE

*Significant on level $\mathrm{p}<0.05$

Also, results of multiple regression show that anxiety is a significant predictor of inhibition $(\mathrm{F}=59.282, \mathrm{p}=0.000)$ and it explains $30.2 \%$ variance of inhibition.

\begin{tabular}{|c|c|c|c|c|c|c|}
\hline & $\Delta \mathrm{R}$ & $\mathrm{F}$ & SIG. & $\mathrm{B}$ & $\mathrm{t}$ & SIG. \\
\hline ANXIETY & .302 & 59.282 & .000 & .550 & 7.699 & .000 \\
\hline
\end{tabular}

TABLE 4: ANXIETY AS PREDICTOR OF INHIBITION

*Significant on level $\mathrm{p}<0.05$

Presented results show that anxiety is a significant predictor in predicting system of inhibition, BAS, BIS, and avoidance. Adolescents with rendered anxiety exhibit inability to react to situations they consider as dangerous, step back and avoid situations which provoke experience of threat, avoid new situations, regardless of their attraction, perceive environment as a source of potential danger, and alike. These individuals can be described as extremely cautious, inhibited, and anxious.

CONCLUSION Results confirm the basic assumption of relationship between anxiety and reinforcement sensitivity and predictive power of trait anxiety in predicting patterns of adolescents' reactions. More precisely, trait anxiety is more exhibited in those adolescents with rendered inhibition and avoidance, as a system of behavioural inhibition, while a system of behavioural activation is lower. Adolescents with rendered anxiety exhibited inability to react to endangering situation, they step back to avoid new situations and perceive their environment as a source of potential danger.

The paper is a modest contribution to a better understanding and use of reformulated Gray's reinforcement sensitivity theory on our population. We would like to state that paper limitations are conditioned by the sample selection, while the directions for a future study should be pointed to the treatment of anxiety as criteria, and 
the basic system of reformulated reinforcement theory of sensitivity as a predictor.

REFERENCES Corr, P. (2004). The Reinforcement Sensitivity Theory of Personality. Neuroscience and Biobehavioral Reviews, 28, 317-332.

Brdarić, D. \& Gavrilov-Jerković, V. (2011). Dimenzije ličnosti reformulisane teorije osetljivosti na potkrepljenje i atribucioni stilovi kao prediktori strategija prevladavanja stresa. Primenjena psihologija, 1, 69-83.

Gray, J. (1985). Issues in the neuropsychological of anxiety. In: J. Maser \& A. Tuma Hussain (Eds.), Anxiety and the Anxiety Disorders (5-25). Hillsdale-London: Lawrence Erlbaum Associates.

Gray, J. A., \& McNaughton, N. (2003). The Neuropsychology of Anxiety. Oxford: Oxford University Press.

Mitrović, D., Smederevac, S., Čolović, P. (2008). Evaluacija reformulisane teorije osetljivosti na potkrepljenje. Psihologija, 41 (4), 555-575.

Spielberger, C. D. (2000). Priručnik za Upitnik anksioznosti kao stanja i osobine ličnosti. STAI Jastrebarsko: Naklada Slap.

Spielberger, C. D., Gorsuch R. L., Lushene R. E. (1970). Manual for the State-Trait Inventory. Palo Alto: Consulting Psychological Press.

Smederevac, S., Mitrović, D., Čolović, P. (2010). Velikih Pet plus Dva. Beograd: Centar za primenjenu psihologiju.

Smederevac, S., Čolović, P., Mitrović, D. (2009). Procena osetljivosti na potkrepljenje (UOP-upitnik), U: M. Biro, S. Smederevac, Z. Novović. (ur.), Procena psiholoških i psihopatoloških fenomena. Beograd (89-100). Centar za primenjenu psihologiju.

Taylor, S. (1995). Issues in the conceptualization and measurement of anxiety sensitivity. Journal of Anxiety Disorders, 9, 163-174.

Tovilović, S. \& Novović, Z. (2009). Procena anksioznosti kao crte (AT29 skala). U: M. Biro, S. Smederevac, Z. Novović. (ur.), Procena psiholoških i psihopatoloških fenomena (55-62). Beograd: Centar za primenjenu psihologiju.

Žuljević, D. \& Gavrilov-Jerković, V. (2011). Strategije prevladavanja stresa u kontekstu teorije osetljivosti na potkrepljenje. Primenjena psihologija, 1, 35-52.

Vulić-Prtorić, A. (2006). Anksiozna osjetljivost: fenomenologija i teorije. Suvremena psihologija, 9 (2), 171-193. 
МИЉАНА С. ПАВИЋЕВИЋ

ЈЕЛЕНА Љ. МИНИЋ

УНИВЕРЗИТЕТ У ПРИШТИНИ СА ПРИВРЕМЕНИМ СЕДИШТЕМ

У КОСОВСКОЈ МИТРОВИЦИ, ФИЛОЗОФСКИ ФАКУЛТЕТ

КАТЕДРА ЗА ПСИХОЛОГИЈУ

РЕЗИМЕ

\author{
АНКСИОЗНОСТ КАО ЦРТА И ОСЕТЉИВОСТ \\ НА ПОТКРЕПЉЕЊЕ КОД АДОЛЕСЦЕНАТА
}

Теоријску основу рада чине реформулисана Грејова теорија осетљивости на поткрепљење и Спиелбергеров модел анксиозности као црте личности. Реч је о утемељеној и добро познатој концепцији, али и тероији која изазива бројне противуречности. Рад је део ширег истраживања менталног здравља младих на Косову и Метохији. Циљ истраживања био је испитати предиктивну моћ анксиозности као црте у предвиђању осетљивости на поткрепљење (кроз системе: БББ; БИС и БАС). Узорак истраживања чинили су адолесценти (H=138). Резултати указују на то да је анксиозност као црта израженија код оних адолесцената код којих су ठлокирање и бежање израженији, као и БИС. Такође, анксиозност је као црта израженија код оних адолесцената код којих је БАС нижи. Није добијена статистички значајна повезаност анксиозности као црте и борбе. Особе са израженијом анксиозношћу испољавају неспособност да одреагују на угрожавајуће ситуације, повлаче се и избегавају нове ситуације, а окружење перципирају као извор потенцијалне опасности.

КљУчнЕ РЕчИ: анксиозност; осетљивост на поткрепљење; адолесцент.

Овај чланак је објављен и дистрибуира се под лиценцом Creative Commons

Ауторство-Некомерцијално Међународна 4.0 (СС BY-NC 4.0|

https://creativecommons.org/licenses/by-nc/4.0/).

This paper is published and distributed under the terms and conditions of the Creative Commons Attribution-NonCommercial International 4.0 licence (CC BY-NC 4.0 | https://creativecommons.org/licenses/by-nc/4.0/). 